\title{
一様勾配斜面上の有限振幅長波について ON THE FINITE AMPLITUDE LONG WAVES ON UNIFORM SLOPE BEACHES
}

\author{
岩 垣 雄 一*・酒 井 哲 郎** \\ By Yuichi Iwagaki and Tetsuo Sakai
}

\section{1. まえがき}

波が深海から浅海に進入すると，底面の影響をうけて いろいろと変形する。特に, 水深の減少に伴う波の変形 に関しては，実用上の面からは，水平床での波のエネル ギー・フラックスを計算し，水深が減少しても，そのエ ネルギー・フラックスが一定であると仮定して, 波高, 波速および波長の変化を求めるのが普通である ${ }^{1), 2) 。 一 ~}$ 方, 水深の変化を境界条件そのものとして取り入れ, 斜面上での波の解を求めようとした研究もなされてい $る^{3), 4)}$ 。以上の理論的研究に対し, 実験および観測によ る研究もかなり行なわれている。特に, 波高, 波速およ び波長の変化に関しては，上述の波のエネルギー・フラ ックスを, 有限振幅波理論によって求めた理論曲線が実 験結果とほぼ一致し, このような近似的な方法で十分説 明できることがわかった ${ }^{5)}$ 。

しかしながら，実験水槽で一様勾配の斜面上を進行し 砕波にいたる波を観測すればわかるように，破波点に近 づくにつれて，波高が増加するだけでなく，波形そのも のが非対称な前かがみの波形になる5 田6) が指摘しているように, 砕波高が斜面勾配によって 変化することが実験的にわかっている。砕波にいたるま えの変形においても, 同様に斜面勾配の影響のあること が予想される。これらの 2 つの問題, すなわち波形の非 対称性および斜面勾配の影響に関しては，上述の水平床 の波理論のエネルギー・フラックスを用いる近似的方法 では何ら説明し得ないことは明らかである。これらにつ いては, 前述の斜面の存在をそのまま境界条件に入れて 理論解を求める方法により説明しらるものと考えられ る。しかしながら, 従来のこの種の研究では, 上述の 2 つの点を明らかにするような解が与えられておらず，た だ $1 つ \mathrm{Biesel}^{7)}$ が波形の前かがみの程度を表わす代表 的な量を提案しているにすぎない。

ここでは, 波形の非対称性と, 変形に及ぼす底勾配の

* 正会員 工博 京都大学教授 工学部土木工学科

** 正会員 工修 京都大学助教授 工学部土木工学科
影響を明らかにするために, 底勾配が一様な 2 次元の海 浜上での波の変形を解析的に取扱う。この海浜上の波の 解を求める方法として，2つの近似法, 寸なわち微小振 幅近似と浅水近似とが考えられるが，ここでは浅水近似 を用い, 浅水理論 (shallow water theory) の最低次の もの ${ }^{8)}$ をの基本方程式とする。この方程式は非線型で あり, その線型解はすでに求められているが9), 上述の 2 つの問題はこの非線型効果を明らかにすることによっ て説明できると考えられる。すでに，この最低次の浅水 理論の 非線型効果を解いた例 ${ }^{10), 11)}$ があるが，これらの 例でも上述の 2 つの問題に対しては明確な解答を与えて いない。特に, 市栄 ${ }^{11}$ は解を波高・水深比のべき級数展 開で表現し，一様勾配斜面上の第 2 次近似解を求めてい るが, 解の中に積分表示が存在し, 一般的取扱いが困難 なため, 斜面の勾配が緩やかな場合の砕波点について数 学的に検討しているにすぎない。ここでは, 上記の $2 つ$ の問題に関して, 明確な表現を得るため, 市栄と同様に せつ動法を用いて非線型効果を考虑し, さらに円柱関数 の三角関数による漸近展開を用いることによって, 一様 勾配の斜面上を進行する有限振幅長波の一般的な解を求 めることにする。

\section{2. 解の誘導}

\section{（1）基本方程式}

2 次元の場合を考え，図一1 のように座標系をとる と, 浅水理論の第 1 近似は次のようになる。

$$
\left.\begin{array}{l}
u_{t}+u \cdot u_{x}+g \cdot \eta_{x}=0 \\
\eta_{t}+\{u \cdot(\eta+h)\}_{x}=0
\end{array}\right\}
$$

ここで, $h=h(x)$ は水深, $\eta=\eta(x, t)$ は静水面からの 水位, $u=u(x, t)$ は $x$ 方向の 水粒子速度 であり, 鉛直 座標には関係しない。このことは，よく知られているよ うに圧力が静水圧で近似できることを意味する。なお, 添字 $t$ および $x$ は，それぞれ $t$ および $x$ に関する微分 を表わす。式（1）は明らかに非線型であり，特性曲線 法を用いて数值計算されることが多い。ここでは，非線 


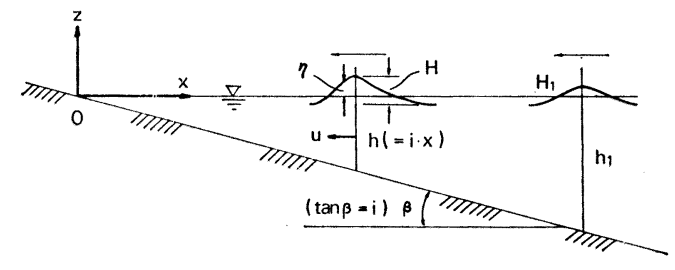

図-1 座標系

型の効果を解析的に表現するため，せつ動法を用いる。 すなわち, $\alpha$ を微小量として, $\eta$ と $u$ を次のよらに展 開できるものとする。 $\alpha の$ 具体的な表現はのちに与え る。

$$
\left.\begin{array}{l}
\eta=\alpha \cdot \eta^{(1)}+\alpha^{2} \cdot \eta^{(2)}+\cdots \cdots \\
u=\alpha \cdot u^{(1)}+\alpha^{2} \cdot u^{(2)}+\cdots \cdots
\end{array}\right\}
$$

式（2）を式（1）に代大して， 。について整理すれば, $\alpha$ の係数は,

$$
\left.\begin{array}{l}
u^{(1)}+g \cdot \eta^{(1)} x=0 \\
\eta^{(1)}+\left\{u^{(1)} \cdot h\right\}_{x}=0
\end{array}\right\}
$$

$\alpha^{2}$ の係数は,

$$
\left.\begin{array}{l}
u^{(2)}+u^{(1)} \cdot u^{(1)}{ }_{x}+g \cdot \eta^{(2)}{ }_{x}=0 \\
\eta^{(2)}+\left\{u^{(1)} \cdot \eta^{(1)}+u^{(2)} \cdot h\right\}_{x}=0
\end{array}\right\}
$$

となる。

\section{（2）第 1 次近似解}

式（3）で $u^{(1)}$ を消去すると次式のようになる。

$$
\eta^{(1)} t t-g \cdot\left\{\eta^{(1)} x \cdot h\right\}_{x}=0
$$

いま, 一様勾配 $i$ の斜面上の波を考えているから，水 水深 $h$ と水平座標 $x$ との関係 $h=i \cdot x$ (図一1 参照) を 上式に代入すると, 一様勾配の斜面上の場合, 式 (5) は 次式のようになる。

$$
\eta_{t t}^{(1)}-g \cdot\left\{\eta^{(1)} x x \cdot i \cdot x+\eta^{(1)} \cdot i\right\}=0
$$

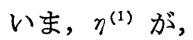

$$
\eta^{(1)}(x, t)=\eta(x) \cdot \cos \sigma t
$$

のように表わされると仮定し, 式 (7) を式 (6) に代入 すると, $\eta(x)$ に関する方程式が 次式のように求まる。

$$
x \cdot \eta_{x x}+\eta_{x}+\left(\sigma^{2} / g i\right) \cdot \eta=0
$$

ここで, 次式の関係 ${ }^{12}$

$$
x=\left(g i / 4 \sigma^{2}\right) \cdot w^{2}
$$

によって, 独立変数を $x$ から $w$ に変数変換すると, 式 (8) は次式のようになる。

$$
\eta_{w w}+(1 / w) \cdot \eta_{w}+\eta=0
$$

式 (10) がその基本解として, 第 1 種円柱関数のベッ セル関数 $\mathrm{J}_{0}(w)$ および第 2 種円柱関数のノイマン関数 $\mathrm{N}_{0}(w)$ をむつことは明らかである。 $\eta^{(1)}$ を，

$$
\eta^{(1)}(x, t)=\eta(x) \cdot \sin \sigma t
$$

と仮定した場合もまったく同様の結果が得られる。円柱 関数の性質として, $x \rightarrow \infty$ すなわち $w \rightarrow \infty$ の場合に,

$$
\left.\begin{array}{l}
\mathrm{J}_{\nu}(w) \sim \sqrt{2 / \pi w} \cdot \cos (w-\nu \cdot \pi / 2-\pi / 4) \\
\mathrm{N}_{\nu}(w) \sim \sqrt{2 / \pi w} \cdot \sin (w-\nu \cdot \pi / 2-\pi / 4)
\end{array}\right\}
$$

と漸近展開されることを考えると, $\eta^{(1)}$ の解として, 図 一1 の沖から岸へ向けて, すなわち $x$ の負の方向に進行 する波に対応する解は,

$$
\begin{aligned}
\eta^{(1)}(x, t)= & a \cdot\left\{\cos \sigma t \cdot \mathrm{J}_{0}\left(2 \sigma \sqrt{\frac{x}{g i}}\right)\right. \\
& \left.-\sin \sigma t \cdot \mathrm{N}_{0}\left(2 \sigma \sqrt{\frac{x}{g i}}\right)\right\}
\end{aligned}
$$

で与えられる9。ここで れる定数である。いま, 円柱関数 $Z_{0}(w), Z_{1}(w)$ の性 質,

$$
\left.\begin{array}{l}
Z_{0}{ }^{\prime}(w)=-Z_{1}(w) \\
Z_{1}^{\prime}(w)=Z_{0}(w)-w^{-1} \cdot Z_{1}(w)
\end{array}\right\}
$$

を用いると, 式 (3) と式 (13) から， $u^{(1)}$ が次式のよ らに求まる。ただし, 記号'は独立変数に関する微分を 表わす。

$$
\begin{aligned}
u^{(1)}(x, t)= & a \sqrt{\frac{g}{i}} \cdot x^{-1 / 2} \cdot\left\{\sin \sigma t \cdot \mathrm{J}_{1}\left(2 \sigma \sqrt{\frac{x}{g i}}\right)\right. \\
& \left.+\cos \sigma t \cdot \mathrm{N}_{1}\left(2 \sigma \sqrt{\frac{x}{g i}}\right)\right\} \cdots \cdots(15)
\end{aligned}
$$

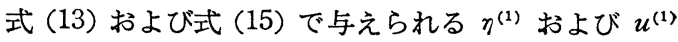
は, 式 (1) の浅水近似の第 1 次近似である 線型解に対 応するものである。式 (13) の $\mathrm{J}_{0}$ および $\mathrm{N}_{0}$ の性質か ら， $x$ が小さくなるにつれて $\eta^{(1)}$ の振幅が増大寸る。 すなわち $\eta^{(1)}$ は, 波が沖から岸に進行するにつれて波

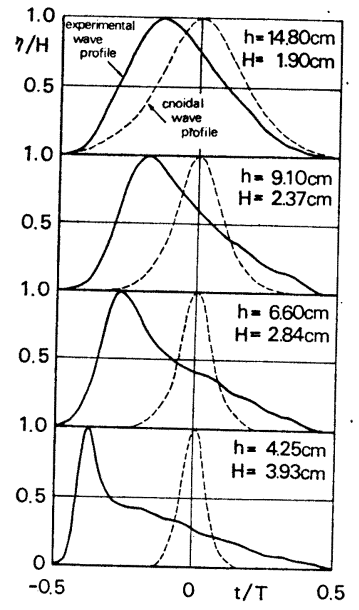

図一2 斜面上の波の非対称な 波形 ${ }^{182}$
高が増大する事実を定性 的に説明しらるものであ る。しかしながら，実験 水槽の斜面上を波が進行 するときは, 水深の減少 に伴って変形し砕波にい たる波の波形を見ればわ かるように（図一2 の実 線，ただし図中の $\eta$ は波 の谷からの水位), 時間 波形が非対称な前かがみ の形となり，波の峯の前 面がきりたってくる。式 (13) で与えられる 線型 解 $\eta^{(1)}$ は, 時間 $t$ に関 しては明らかに正弦関数 の形をむち，波形が前かがみになる実験事実を説明する ことができない。ここでは，基本式（1）の非線型の項 が, 波形の非対称性を説明しらるのではないかと考え， すでに求められた $\eta^{(1)}$ および $u^{(1)}$ を用いて， $\eta^{(2)}$ を求 めてみることにする。 


\section{（3）第 2 次近似解}

式 (4) において $u^{(2)}$ を消去し， $h=i \cdot x$ の関係（図 -1 参照) を用いると, 次式が得られる。

$$
\begin{aligned}
& \eta^{(2)} t t-g \cdot\left\{\eta^{(2)} x x \cdot i \cdot x+\eta^{(2)} x \cdot i\right\} \\
& =-\left\{u^{(1)} \cdot \eta^{(1)}\right\}_{x t}+\left\{u^{(1)} \cdot u^{(1)}\right\}_{x} \cdot i \cdot x \\
& +\left\{u^{(1)} \cdot u^{(1)} x\right\} \cdot i
\end{aligned}
$$

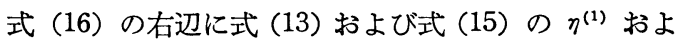
び ‘(1) を代入し，式 (14) の関係を用いて整理すると， 式 (16) の右辺は次のようになる。

式 (16) の右辺 $=\cos 2 \sigma t \cdot\left\{-\frac{3}{2} a^{2} \frac{\sigma^{2}}{i} x^{-1}\right.$

$$
\begin{aligned}
& \cdot\left(\mathrm{J}_{0}{ }^{2}-\mathrm{J}_{1}{ }^{2}-\mathrm{N}_{0}{ }^{2}+\mathrm{N}_{1}{ }^{2}\right)+\frac{5}{2} a^{2} \sqrt{\frac{g}{i}} \cdot \sigma \cdot x^{-3 / 2} \\
& \left.\cdot\left(\mathrm{J}_{0} \mathrm{~J}_{1}-\mathrm{N}_{0} \mathrm{~N}_{1}\right)-a^{2} \cdot g \cdot x^{-2} \cdot\left(\mathrm{J}_{1}{ }^{2}-\mathrm{N}_{1}{ }^{2}\right)\right\} \\
& +\sin 2 \sigma t \cdot\left\{3 a^{2} \frac{\sigma^{2}}{i} x^{-1} \cdot\left(\mathrm{J}_{0} \mathrm{~N}_{0}-\mathrm{J}_{1} \mathrm{~N}_{1}\right)\right. \\
& -\frac{5}{2} a^{2} \sqrt{\frac{g}{i}} \cdot \sigma \cdot x^{-3 / 2} \cdot\left(\mathrm{J}_{1} \mathrm{~N}_{0}+\mathrm{J}_{0} \mathrm{~N}_{1}\right) \\
& \left.+2 a^{2} \cdot g \cdot x^{-2} \cdot \mathrm{J}_{1} \mathrm{~N}_{1}\right\} \\
& +\frac{1}{2} a^{2} \frac{\sigma^{2}}{i} x^{-1} \cdot\left(\mathrm{J}_{0}{ }^{2}-\mathrm{J}_{1}{ }^{2}-\mathrm{N}_{0}{ }^{2}+\mathrm{N}_{1}{ }^{2}\right) \\
& -\frac{3}{2} a^{2} \sqrt{\frac{g}{i}} \cdot \sigma \cdot x^{-3 / 2} \cdot\left(\mathrm{J}_{0} \mathrm{~J}_{1}-\mathrm{N}_{0} \mathrm{~N}_{1}\right) \\
& +a^{2} \cdot g \cdot x^{-2} \cdot\left(\mathrm{J}_{1}{ }^{2}-\mathrm{N}_{1}{ }^{2}\right)
\end{aligned}
$$

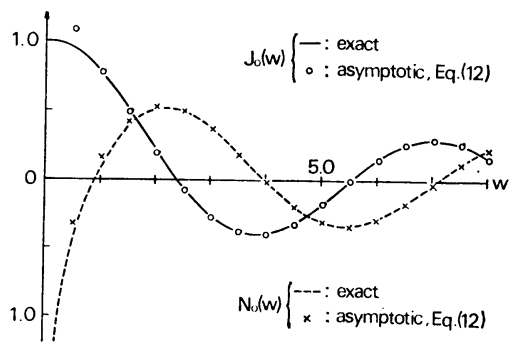

图一-3 ベッセル関数とノイマン関数の

濑近展開による近似值

さて, 図一3に, Joおよび $\mathrm{N}_{0}$ の悠密な值と式 (12) による近似值の比較を示しているが，wの值がある程 度以上になると, 式 (12) の漸近展開による值は十分正 確であることがわかる。いま, 式 (16) の解 $\eta^{(2)}$ を求 めやすいように,その右辺である式 (17) の円柱関数を, 式（12）を用いて三角関数で近似すると, 次式のように なる。

式 (16) の右辺 $=\cos 2 \sigma t$

$$
\begin{aligned}
& \cdot\left[-3 a^{2} \frac{\sigma}{\pi} \sqrt{\frac{g}{i}} \cdot x^{-3 / 2} \cdot \cos \left\{2\left(2 \sigma \sqrt{\frac{x}{g i}}-\frac{\pi}{4}\right)\right\}\right. \\
& +\frac{5}{2} a^{2} \frac{g}{\pi} x^{-2} \cdot \sin \left\{2\left(2 \sigma \sqrt{\frac{x}{g i}}-\frac{\pi}{4}\right)\right\}
\end{aligned}
$$

$$
\begin{aligned}
& \left.+a^{2} \frac{g}{\pi \sigma} \sqrt{g i} \cdot x^{-5 / 2} \cdot \cos \left\{2\left(2 \sigma \sqrt{\frac{x}{g i}}-\frac{\pi}{4}\right)\right\}\right] \\
& +\sin 2 \sigma t \cdot\left[3 a^{2} \frac{\sigma}{\pi} \sqrt{\frac{g}{i}} \cdot x^{-3 / 2}\right. \\
& -\sin \left\{2\left(2 \sigma \sqrt{\frac{x}{g i}}-\frac{\pi}{4}\right)\right\} \\
& +\frac{5}{2} a^{2} \frac{g}{\pi} \cdot x^{-2} \cdot \cos \left\{2\left(2 \sigma \sqrt{\frac{x}{g i}}-\frac{\pi}{4}\right)\right\} \\
& \left.-a^{2} \frac{g}{\pi \sigma} \sqrt{g i} \cdot x^{-5 / 2} \cdot \sin \left\{2\left(2 \sigma \sqrt{\frac{x}{g i}}-\frac{\pi}{4}\right)\right\}\right] \\
& +\left[a^{2} \frac{\sigma}{\pi} \sqrt{\frac{g}{i}} \cdot x^{-3 / 2} \cdot \cos \left\{2\left(2 \sigma \sqrt{\frac{x}{g i}}-\frac{\pi}{4}\right)\right\}\right. \\
& -\frac{3}{2} a^{2} \frac{g}{\pi} \cdot x^{-2} \cdot \sin \left\{2\left(2 \sigma \sqrt{\frac{x}{g i}}-\frac{\pi}{4}\right)\right\} \\
& \left.-a^{2} \frac{g}{\pi \sigma} \sqrt{g i} \cdot x^{-5 / 2} \cdot \cos \left\{2\left(2 \sigma \sqrt{\frac{x}{g i}}-\frac{\pi}{4}\right)\right\}\right]
\end{aligned}
$$

いま, 式（16）の右辺が式（18）で表わされる場合の 解 $\eta^{(2)}$ として, 次式を仮定する。

$$
\begin{aligned}
\eta^{(2)}(x, t)= & \cos 2 \sigma t \cdot A(x) \\
& +\sin 2 \sigma t \cdot B(x)+C(x)
\end{aligned}
$$

この $\eta^{(2)}$ を式 (16) の左辺に代入すると,

式 (16) の左辺 $=\cos 2 \sigma t \cdot\left\{-4 \sigma^{2} \cdot A(x)\right.$

$$
\begin{aligned}
& \left.-g \cdot i \cdot x \cdot A^{\prime \prime}(x)-g \cdot i \cdot A^{\prime}(x)\right\} \\
& +\sin 2 \sigma t \cdot\left\{-4 \sigma^{2} \cdot B(x)\right. \\
& \left.-g \cdot i \cdot x \cdot B^{\prime \prime}(x)-g \cdot i \cdot B^{\prime}(x)\right\} \\
& +\left\{-g \cdot i \cdot x \cdot C^{\prime \prime}(x)-g \cdot i \cdot C^{\prime}(x)\right\}
\end{aligned}
$$

となる。したがって, 式 (20) の $\cos 2 \sigma t$ の係数, $\sin 2 \sigma t$ の係数および $t$ 亿無関係な項が, それぞれ式 (18) の対応する項に一致するように $A(x), B(x)$ およ び $C(x)$ をきめれば解 $\eta^{(2)}$ が求まる。そこで, 次式の ような表現を与えてみる。

$$
\begin{aligned}
A(x)= & -a^{2} \frac{1}{\pi i} x^{-1} \cdot \sin \left\{2\left(2 \sigma \sqrt{\frac{x}{g i}}-\frac{\pi}{4}\right)\right\} \\
& -\frac{3}{10} a^{2} \frac{1}{\pi \sigma} \sqrt{\frac{g}{i}} \cdot x^{-3 / 2} \\
& \cdot \cos \left\{2\left(2 \sigma \sqrt{\frac{x}{g i}}-\frac{\pi}{4}\right)\right\} \cdots \cdots \cdots(21) \\
B(x)= & -a^{2} \frac{1}{\pi i} x^{-1} \cdot \cos \left\{2\left(2 \sigma \sqrt{\frac{x}{g i}}-\frac{\pi}{4}\right)\right\} \\
& +\frac{3}{10} a^{2} \frac{1}{\pi \sigma} \sqrt{\frac{g}{i}} \cdot x^{-3 / 2} \\
& \cdot \sin \left\{2\left(2 \sigma \sqrt{\frac{x}{g i}}-\frac{\pi}{4}\right)\right\} \cdots \cdots \cdots \cdots(22) \\
C(x)= & \frac{1}{4} a^{2} \frac{1}{\pi \sigma} \sqrt{\frac{g}{i}} \cdot x^{-3 / 2} \\
\cdot & \cos \left\{2\left(2 \sigma \sqrt{\frac{x}{g i}}-\frac{\pi}{4}\right)\right\}-\frac{1}{16} a^{2} \frac{g}{\pi \sigma^{2}} \cdot x^{-2} \\
& \cdot \sin \left\{2\left(2 \sigma \sqrt{\frac{x}{g i}}-\frac{\pi}{4}\right)\right\} \cdots \cdots \cdots \cdots \cdots(23)
\end{aligned}
$$


以上の 3 式を式 (20) に代入すると, 結局式 (16) の 左辺は次式のようになる。

式 (16) の左辺 $=\cos 2 \sigma t$

$$
\begin{aligned}
& \cdot\left[-3 a^{2} \frac{\sigma}{\pi} \sqrt{\frac{g}{i}} \cdot x^{-3 / 2} \cdot \cos \left\{2\left(2 \sigma \sqrt{\frac{x}{g i}}-\frac{\pi}{4}\right)\right\}\right. \\
& +\frac{5}{2} a^{2} \frac{g}{\pi} x^{-2} \cdot \sin \left\{2\left(2 \sigma \sqrt{\frac{x}{g i}}-\frac{\pi}{4}\right)\right\} \\
& \left.+\frac{27}{40} a^{2} \frac{g}{\pi \sigma} \sqrt{g i} \cdot x^{-5 / 2} \cdot \cos \left\{2\left(2 \sigma \sqrt{\frac{x}{g i}}-\frac{\pi}{4}\right)\right\}\right] \\
& +\sin 2 \sigma t \cdot\left[3 a^{2} \frac{\sigma}{\pi} \sqrt{\frac{g}{i}} \cdot x^{-3 / 2}\right. \\
& \cdot \sin \left\{2\left(2 \sigma \sqrt{\frac{x}{g i}}-\frac{\pi}{4}\right)\right\} \\
& +\frac{5}{2} a^{2} \frac{g}{\pi} x^{-2} \cdot \cos \left\{2\left(2 \sigma \sqrt{\frac{x}{g i}}-\frac{\pi}{4}\right)\right\} \\
& \left.-\frac{27}{40} a^{2} \frac{g}{\pi \sigma} \sqrt{g i} \cdot x^{-5 / 2} \cdot \sin \left\{2\left(2 \sigma \sqrt{\frac{x}{g i}}-\frac{\pi}{4}\right)\right\}\right] \\
& +\left[a^{2} \frac{\sigma}{\pi} \sqrt{\frac{g}{i}} \cdot x^{-3 / 2} \cdot \cos \left\{2\left(2 \sigma \sqrt{\frac{x}{g i}}-\frac{\pi}{4}\right)\right\}\right. \\
& -\frac{3}{2} a^{2} \frac{g}{\pi} \cdot x^{-2} \cdot \sin \left\{2\left(2 \sigma \sqrt{\frac{x}{g i}}-\frac{\pi}{4}\right)\right\} \\
& -a^{2} \frac{g}{\pi \sigma} \sqrt{g i} \cdot x^{-5 / 2} \cdot \cos \left\{2\left(2 \sigma \sqrt{\frac{x}{g i}}-\frac{\pi}{4}\right)\right\} \\
& \left.+\frac{1}{4} a^{2} \frac{g^{2}}{\pi \sigma^{2}} \cdot i \cdot x^{-3} \cdot \sin \left\{2\left(2 \sigma \sqrt{\frac{x}{g i}}-\frac{\pi}{4}\right)\right\}\right]
\end{aligned}
$$

式 (24) を式 (18) と比較してわかるように, $\cos 2 \sigma t$ および $\sin 2 \sigma t$ にかかる第 3 項の定係数が異なり,また $t$ に無関係な項では, 式（18）にはない第 4 項が余分に ある。ここで, それらの各項の大きさを比較してみる。 $\cos 2 \sigma t$ および $\sin 2 \sigma t$ の各項は,それぞれ順に $x^{-3 / 2}$, $x^{-2}$ および $x^{-5 / 2}$ を含み, $t$ に無関係な項では式 (24) にさらに $x^{-3}$ を含む第 4 項が存在する。しかも $x$ のべ きの等しい項は，定係数を除いて等しい。いま，それら の第 2〜第 4 項 の大きさを第 1 項と比較してみると, $\sigma=2 \pi / T$ および $x=h \cdot i^{-1}$ を考慮して,

第 2 項/第 1 項 $\{(g T / 2 \pi) / \sqrt{g h}\} \cdot i$

第 3 項/第 1 項 $[\{(g T / 2 \pi) / \sqrt{g h}\} \cdot i]^{2}$

第 4 項/第 1 項 $[\{(g T / 2 \pi) / \sqrt{g h}\} \cdot i]^{3}$

となり, 第 1 , 第 2 , 第 3 および第 4 項の順に底勾配 $i$ のオーダで小さくなることがわかる。

式（18）と式（24）を比較して, $\cos 2 \sigma t$ および $\sin 2 \sigma t$ にかかる各項の中の定係数が異なる第 3 項は, 第 1 項と同じく

および

$$
\cos \left\{2\left(2 \sigma \sqrt{\frac{x}{g i}}-\frac{\pi}{4}\right)\right\}
$$

$$
\sin \left\{2\left(2 \sigma \sqrt{\frac{x}{g i}}-\frac{\pi}{4}\right)\right\}
$$

を含み同位相であり，その比は $[\{(g T / 2 \pi) / \sqrt{g h}\} \cdot i]^{2}$
であって,たとえば底勾配 $1 / 10$, 水深 $20 \mathrm{~cm}$, 波の周期 $3 \mathrm{sec}$ の場合を考えると $1 / 10$ 以下であり，第 3 項の定 係数の不一致は 無視してよいと思われる。また $t$ に無 関係な項で, 式 (24) にのみ存在する第 4 項は, 第 2 項 と同じく $\sin \left\{2\left(2 \sigma \sqrt{\frac{x}{g i}}-\frac{\pi}{4}\right)\right\}$ を含み同位相であり， その比はやはり $[\{(g T / 2 \pi) / \sqrt{g h} \cdot\} \cdot i]^{2}$ であって, これ も無視してよいことがわかる。

以上の理由から, 式 (19) と式 (21), 式 (22) およ び式 (23) を, 式 (16) を満たす解 $\eta^{(2)}$ とする。結局 $\eta^{(2)}$ は, 次式のように表わされる。

$$
\begin{aligned}
\eta^{(2)} & (x, t)=\cos 2 \sigma t \cdot\left[-a^{2} \frac{1}{\pi i} x^{-1}\right. \\
\cdot & \sin \left\{2\left(2 \sigma \sqrt{\frac{x}{g i}}-\frac{\pi}{4}\right)\right\} \\
- & \left.\frac{3}{10} a^{2} \frac{1}{\pi \sigma} \sqrt{\frac{g}{i}} \cdot x^{-3 / 2} \cdot \cos \left\{2\left(2 \sigma \sqrt{\frac{x}{g i}}-\frac{\pi}{4}\right)\right\}\right] \\
+ & \sin 2 \sigma t \cdot\left[-a^{2} \frac{1}{\pi i} x^{-1} \cdot \cos \left\{2\left(2 \sigma \sqrt{\frac{x}{g i}}-\frac{\pi}{4}\right)\right\}\right. \\
+ & \left.\frac{3}{10} a^{2} \frac{1}{\pi \sigma} \sqrt{\frac{g}{i}} \cdot x^{-3 / 2} \cdot \sin \left\{2\left(2 \sigma \sqrt{\frac{x}{g i}}-\frac{\pi}{4}\right)\right\}\right] \\
+ & {\left[\frac{1}{4} a^{2} \frac{1}{\pi \sigma} \sqrt{\frac{g}{i}} \cdot x^{-3 / 2} \cdot \cos \left\{2\left(2 \sigma \sqrt{\frac{x}{g i}}-\frac{\pi}{4}\right)\right\}\right.} \\
- & \left.\frac{1}{16} a^{2} \frac{g}{\pi \sigma^{2}} \cdot x^{-2} \cdot \sin \left\{2\left(2 \sigma \sqrt{\frac{x}{g i}}-\frac{\pi}{4}\right)\right\}\right] \cdots(25)
\end{aligned}
$$

なお, 式 (13) で与えられる線型解 $\eta^{(1)}$ は, 式 (12) を用いて円柱関数を三角関数で表現すると, 次式のよう になる。

$$
\begin{aligned}
\eta^{(1)}(x, t)= & a \cdot(\sqrt{g i} / \pi \sigma)^{1 / 2} \cdot x^{-1 / 4} \\
& \cdot \cos \left(\sigma t+2 \sigma \sqrt{\frac{x}{g i}}-\frac{\pi}{4}\right)
\end{aligned}
$$

また, 式 (25) を, 式 (26) の $\eta^{(1)}$ と比較しやすいよ らに変形すると, 最終的に次式が得られる。

$$
\begin{aligned}
& \eta^{(2)}(x, t)=a^{2} /(\pi i) \cdot x^{-1} \cdot \cos \left\{2\left(\sigma t+2 \sigma \sqrt{\frac{x}{g i}}-\frac{\pi}{4}\right)\right. \\
& \left.+\frac{\pi}{2}+\tan ^{-1}\left(\frac{3}{10} \frac{\sqrt{g i}}{\sigma} \cdot x^{-1 / 2}\right)\right\} \\
& +\left[\frac{1}{4} a^{2} \frac{1}{\pi \sigma} \sqrt{\frac{g}{i}} \cdot x^{-3 / 2} \cdot \cos \left\{2\left(2 \sigma \sqrt{\frac{x}{g i}}-\frac{\pi}{4}\right)\right\}\right. \\
& \left.-\frac{1}{16} a^{2} \frac{g}{\pi \sigma^{2}} x^{-2} \cdot \sin \left\{2\left(2 \sigma \sqrt{\frac{x}{g i}}-\frac{\pi}{4}\right)\right\}\right] \cdots(27)
\end{aligned}
$$

以後, 式 (26) で与えられる $\eta^{(1)}$ を第 1 次近似解, 式 (27) で与えられる $\eta^{(2)}$ を第 2 次近似解と名うける。

\section{（4）解の適用範囲}

ここで，これらの解の適用範囲について考えてみる。 まず, 用いた基本方程式 (1) は, いわゆる 浅水理論の 最低次のものであり, 圧力が静水圧に等しいと仮定され ており, 波長にくらべて水深がある程度以上小さくない と用いられない。いま一様水深での長波の伝播速度 $\sqrt{g h}$ 
を用いると，

$$
h / L=1 /(T \sqrt{g / h})
$$

となる。適用しうる $h / L$ の值に上限があることは， $T \sqrt{g / h}$ の值に下限のあることであり，波の周期が与え られている場合は，水深 $h$ の值に上限があることを意 味する。一方, 水樑 $h$ の值には下限も存在する。すな わち,ここでは，第 1 次近似解 $\eta^{(1)}$ として式 (13) その ものを用いず，式 (12) の円柱関数の漸近展 開を用い て，円柱関数を三角関数でおきかえた式 (26) を用いて いる。式 (12) は $|w| \rightarrow \infty$ の場合の漸近展開であり， 図一3 に示したようにある程度 $|w|$ の值が大きくない と適用できない。 $\mathrm{J}_{0}, \mathrm{~N}_{0}, \mathrm{~J}_{1}$ および $\mathrm{N}_{1}$ について，それ ぞれの厳密な值とその漸近展開による值とを比較したと ころ，|w| $\mid 21.0$ のときは適用可能であることがわかっ た。この条件を式 (9) に適用し $h=i \cdot x$ の関係を使う と次式のようになる。

$$
T \sqrt{g / h} \leq 4 \pi / i
$$

これから， $T \sqrt{g / h}$ の值に上限，つまり波の周期が与え られている場合, 水深 $h$ に底勾配によって決まる下限 があることがわかる。以上の 2 つの適用限界を図に示し たのが 図一4である。横軸に $T \sqrt{g / h}$, 縦軸に底勾配 $i$ をとって，その適用範囲が斜線をほどこして示してあ る。ただし， $T \sqrt{g / h}$ の下限值は, 図に示したように 2 種類の $h / L$ の限界値について与えてある。

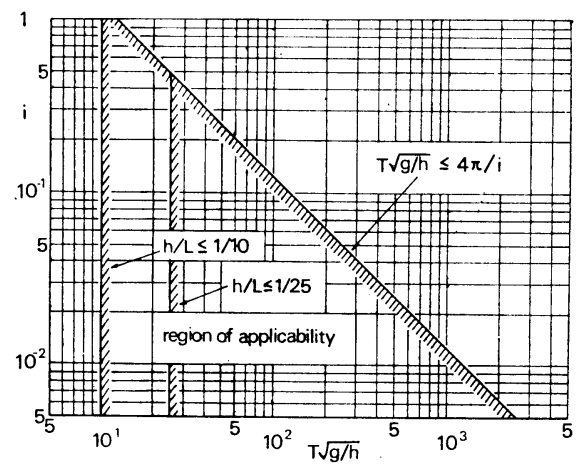

図一４適用籍囲

\section{3. 解の 検 討}

\section{（1）微小量 $\boldsymbol{a}$ の決定}

式 (27) で与えられた $\eta^{(2)}$ の右辺の 第 2 項は, $x^{-3 / 2}$ と $x^{-2}$ の項からなり,第 1 項での $x^{-1}$ の項と大きさを 比較するために振幅の比をとると,それぞれ $\{(g T / 2 \pi) /$ $\sqrt{g h}\} \cdot i$ および $[\{(g T / 2 \pi) / \sqrt{g h}\} \cdot i]^{2}$ となり，第 2 項 全体としては,第 1 項にくらべて $\{(g T / 2 \pi) / \sqrt{g h}\} \cdot i$ 倍 のオーダ小さいことになる。しかも第 2 項は $t$ に無関係
であるから, 静水位に関係するのみで, 波高および波形 には関倸しない。ここでは，1，で述べたように，水深 減少に伴う波高の変化に及ぼす底勾配の影響および波形 の非対称化に注目しているので, 以後の議論では式 (27) の右辺のうち第 2 項を無視する。

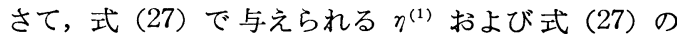
右辺の第 2 項を無視した $\eta^{(2)}$ を式 (2) に代入すると,

$$
\begin{aligned}
\eta(x, t) & =\alpha \cdot a \cdot(\sqrt{g i} / \pi \sigma)^{1 / 2} \cdot x^{-1 / 4} \\
& \cdot \cos \left(\sigma t+2 \sigma \sqrt{\frac{x}{g i}}-\frac{\pi}{4}\right) \\
& +\alpha^{2} \cdot a^{2} /(\pi i) \cdot x^{-1} \cdot \cos \left\{2\left(\sigma t+2 \sigma \sqrt{\frac{x}{g i}}-\frac{\pi}{4}\right)\right. \\
& \left.+\frac{\pi}{2}+\tan ^{-1}\left(\frac{3}{10} \frac{\sqrt{g i}}{\sigma} \cdot x^{-1 / 2}\right)\right\}+\cdots \quad \cdots \cdots(30)
\end{aligned}
$$

となる。ここで, 微小量 $\alpha$ とては, 2.(4) で述べたこ の理論の適用範囲の最媣点での水深 (以後 $h_{1}$ とする) を，微小振幅波の沖波波長 $L_{0}=g T^{2} / 2 \pi$ でわった值 $h_{1} / L_{0}$ をとる。式 (30) のパラメータ $\alpha$ に,

$$
\alpha=h_{1} / L_{0}
$$

を代入すると，次式のようになる。

$$
\begin{aligned}
\eta / h_{1}= & \left(a / L_{0}\right) \cdot(\sqrt{g i} / \pi \sigma)^{1 / 2} \cdot x^{-1 / 4} \cdot \cos \theta \\
& +\left(a / L_{0}\right) \cdot\left(h_{1} / L_{0}\right) \cdot(\pi i)^{-1} \cdot(a / x) \\
& \cdot \cos (2 \theta+\delta) \quad \ldots \ldots \ldots \ldots \ldots \ldots \ldots \ldots \ldots \ldots \ldots \ldots \ldots \ldots \ldots
\end{aligned}
$$

ただし，

$$
\left.\begin{array}{l}
\theta=\sigma t+2 \sigma \sqrt{x / g i}-\pi / 4 \\
\delta=\pi / 2+\tan ^{-1}\left(3 / 10 \cdot \sqrt{g i} / \sigma \cdot x^{-1 / 2}\right)
\end{array}\right\}
$$

\section{（2）定数 $\boldsymbol{a}$ の決定}

水深 $h_{1}$ に抒ける波高 $H_{1}$ と定数 $a$ との関係を知るた め, 式 (32) を簡単に,

$$
\eta / h_{1}=A^{(1)} \cdot \cos \theta+A^{(2)} \cdot \cos (2 \theta+\delta)
$$

と書く。ここで， $A^{(1)}$ および $A^{(2)}$ は式 (32) の各項の 係数であり, 若干の変形を行なうと次式のようになる。

$$
\left.\begin{array}{l}
A^{(1)}=2^{-1 / 4} \cdot \pi^{-3 / 4} \cdot i^{1 / 2} \cdot\left(h_{1} / L_{0}\right)^{3 / 4} \cdot\left(h_{1} / h\right)^{1 / 4} \cdot\left(a / h_{1}\right) \\
A^{(2)}=\pi^{-1} \cdot\left(h_{1} / L_{0}\right)^{2} \cdot\left(h_{1} / h\right) \cdot\left(a / h_{1}\right)^{2}
\end{array}\right\}
$$

また， $\theta$ および $\delta$ は次式で与えられる。

$$
\left.\begin{array}{l}
\theta=2 \pi / T \cdot t+2 \pi\left\{\sqrt{2 / \pi} \cdot\left(h / L_{0}\right)^{-1 / 2}\right\} \cdot x / L_{0}-\pi / 4 \\
\delta=\pi / 2+\tan ^{-1}\left\{3 / 10 \cdot(2 \pi)^{-1 / 2} \cdot i \cdot\left(h / L_{0}\right)^{-1 / 2}\right\}
\end{array}\right\}
$$

$h=h_{1}$ での $A^{(1)}$ および $A^{(2)}$ を，それぞれ $A^{(1)}{ }_{1}, A^{(2)}{ }_{1}$ とおくと,

$$
\left.\begin{array}{l}
A^{(1)}{ }_{1}=2^{-1 / 4} \cdot \pi^{-3 / 4} \cdot i^{1 / 2} \cdot\left(h_{1} / L_{0}\right)^{3 / 4} \cdot\left(a / h_{1}\right), \\
A^{(2)}{ }_{1}=\pi^{-1} \cdot\left(h_{1} / L_{0}\right)^{2} \cdot\left(a / h_{1}\right)^{2}
\end{array}\right\}
$$

となる。なお，式 (36) で与えられる $\delta$ のち $\tan ^{-1}\{\}$ の部分は, $\pi / 2$ にくらべて小さく,ここでは簡単のため 
に $\delta \fallingdotseq \pi / 2$ とする。したがって $\eta_{1} / h_{1}$ は,

$$
\begin{aligned}
\eta_{1} / h_{1} & =A_{1}^{(1)} \cdot \cos \theta+A^{(2)}{ }_{1} \cdot \cos (2 \theta+\pi / 2) \\
& =A^{(1)} \cdot\left\{\cos \theta-\left(A^{(2)}{ }_{1} / A^{(1)}{ }_{1}\right) \cdot \sin 2 \theta\right\} \\
& =A^{(1)}{ }_{1} \cdot f(\theta) \ldots \ldots \ldots \ldots \ldots \ldots \ldots \ldots \ldots \ldots \ldots \ldots \ldots \ldots \ldots \ldots \ldots \ldots \ldots \ldots \ldots \ldots
\end{aligned}
$$

となる。ここで, $f(\theta)$ は次式で与えられる。 $f(\theta)=\cos \theta-b \cdot \sin 2 \theta, b=A^{(2)}{ }_{1} / A^{(1)}$

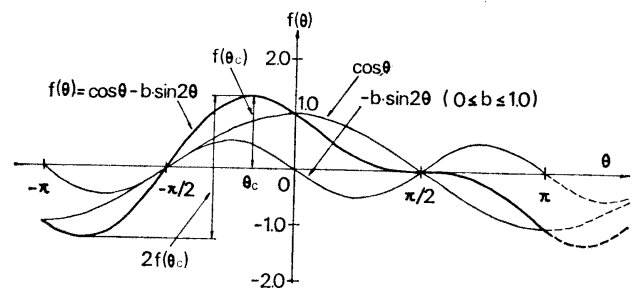

図一5 $f(\theta)$ の 波 形

図一5 は, $f(\theta)$ を $-\pi \leq \theta \leq \pi$ の範囲で示したもので ある。式 (34) で与えられる波形の波高 $H_{1} / h_{1}$ は, 図 -5の $\theta=\theta_{c}$ における縦軸の值 $f\left(\theta_{c}\right)$ から, $A^{(1)}{ }_{1} \times$ $2 f\left(\theta_{c}\right)$ で与えられることは明らかである。 $\theta_{c}$ は， $d f /$ $a \theta=0$ から求まる。すなわち,

$$
\begin{aligned}
d f / d \theta & =-\sin \theta-2 b \cdot \cos 2 \theta \\
& =-\sin \theta_{c}-2 b \cdot\left(1-2 \sin ^{2} \theta_{c}\right)=0 .
\end{aligned}
$$

であるから, $\sin \theta_{c}$ は,

$$
\sin \theta_{c}=\left(1 / 4 b \pm \sqrt{1 / 16 b^{2}+2}\right) / 2
$$

で与えられる。ただし，図一5 からわかるように，一 $\leq \theta_{c} \leq 0$ であるから, $\sin \theta_{c} \leq 0$ である。結局, $\sin \theta_{c}$ は, 次式で与えられる。

$$
\sin \theta_{c}=\left(1 / 4 b-\sqrt{1 / 16 b^{2}+2}\right) / 2 \cdot
$$

一方, $f\left(\theta_{c}\right)$ は, 式 (39) から,

$$
\begin{aligned}
f\left(\theta_{c}\right) & =\cos \theta_{c}-b \cdot \sin 2 \theta_{c} \\
& =\sqrt{1-\sin ^{2} \theta_{c}} \cdot\left(1-2 b \cdot \sin \theta_{c}\right)
\end{aligned}
$$

であるから， $b$ を与えて式 (41) から $\sin \theta_{c}$, 式 (42) か ら $f\left(\theta_{c}\right)$ が求まる。すでに述べたように, 式 (38) か ら $h=h_{1}$ における波高 $H_{1}$ は, 次式で与えられる。

$$
H_{1} / h_{1}=2 \times A_{1}^{(1)} \cdot f\left(\theta_{c}\right)
$$

上式において， $A^{(1)}{ }_{1}$ は式 (37) でわかるように $a / h_{1}$ の 関数であり, $f\left(\theta_{c}\right)$ もまた $b\left(=A^{(2)}{ }_{1} / A^{(1)}{ }_{1}\right)$ すなわち $a / h_{1}$ の関数である。したがって式 (43) から $a / h_{1}$ を求 める場合，実際にはくり返し計算を行なう必要がある。

ここで, 式 (34) で与えられる解の意味を検討するた めに， $h_{1}$ においてはその右辺の第 2 項は第 1 項にくら ベて小さく無視しうるものと仮定する。したがって，第 1 項すなわち第 1 次近似解の振幅の 2 倍が $H_{1}$ となり, この関係を用いて式 (34) を変形すると, 結局, 次式の ようになる。

$$
\begin{aligned}
\eta / h_{1}= & 1 / 2 \cdot\left(H_{1} / h_{1}\right) \cdot\left(h_{1} / h\right)^{1 / 4} \cdot \cos \theta \\
& +\sqrt{2 \pi} \cdot\left(h_{1} / L_{0}\right)^{1 / 2} \cdot i^{-1} \cdot\left(H_{1} / 2 h_{1}\right)^{2}
\end{aligned}
$$

$$
\cdot\left(h_{1} / h\right) \cdot \cos (2 \theta+\delta)
$$

式 (44) からわかるように, 線型解である右辺第 1 項の 振幅は, 水深 $h$ の $1 / 4$ 乗に逆比例し, 底勾配 $i$ には無 関係である。これは従来，反射および波のエネルギーの 損失がない場合のきわめて緩やかな斜面上での長波の変 形に関するGreen の法則 ${ }^{14)}$ として知られているものに 一致する。一方, 非線形の効果を表わす第 2 項は, 第 1 項とくらべて, その振幅は 水深 $h$ の 1 乗に逆比例し, 水深の減少に伴う増加の割合が第 1 項よりはるかに大き い。さらに， $h_{1} / L_{0}$ および底勾配 $i$ にも関係し，特に， 従来明確な 表現がなされていなかった底勾配 $i$ の影響 については， $i$ に逆比例して振幅が増大することがわか る。著者らはさきに, Laitone $\mathrm{e}^{15)}$ のクノイド波の第 2 次 近似解の近似表現であるハイパボリック波理論のエネル ギー・フラックス法に基づく有限振幅長波の shoaling に ついての研究2),5)（図一7 (1) 参照）を発表しているが， この研究の第 1 段階として, それ以前に著者の 1 人 $^{16)}$ は その第 1 次近似の波高変化の理論式を求めている。その 理論式によると, 波高・水深比が小さい場合, 波高が水 深に逆比例して変化し, 式 (44) の第 2 項の振幅と水深 の関係と一致する結果が得られることは興味深い。さら

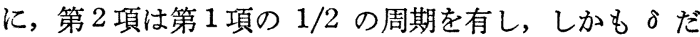

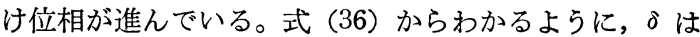
$\pi / 2$ と $\tan ^{-1}\left\{(3 / 10) \cdot(2 \pi)^{-1 / 2} \cdot i \cdot\left(h / L_{0}\right)^{-1 / 2}\right\}$ とからなり， 後者は水深の減少に伴って増加する。したがって, 後述 するように，この位相差によって，波形が前かがみにな ることが説明できるのである。

\section{4. 数值計算結果}

\section{（1）数値計算における制限}

すでに 図一4で示したように, この理論には, 圧力 として静水圧分布を仮定していること，および円柱関数 を三角関数で近似したことによって，与えられた波の周 期 $T$ および底勾配 $i$ にっってきまる $h$ の適用範囲が ある。特に, 静水圧分布の仮定によって決まる適用範囲 の最梁点の水深 $h_{1}$ (図一1 参照) は, 適用限界に扔け る $h / L$ の值のとり方によってかわる。式 (1) で与えら れる浅水近似の最低次のものの適用範囲としては，たと えば,

$$
h / L \leq 1 / 25
$$

という関倸が提案されているが17)，ここではその範囲を 若干抬大し,

$$
h / L \leq 1 / 20
$$

をとる。式 (28) から式 (45) の関倸は,

$$
T \sqrt{g / h} \geq 20
$$


となり，微小振幅波の沖波波長 $L_{0}=g T^{2} / 2 \pi$ を用いる と, 結局適用範囲の最深点 $h_{1}$ は次式で与えられる。

$$
h_{1} / L_{0}=0.0157
$$

さて, 式 (34) および式 (35) で与えられる $\eta / h$ の関 係を用いて,一様な勾配 $i$ の斜面上での水深減少に伴う 波高および波形の変化を求めるには, 水深 $h_{1}$ での波高 $H_{1}$ をあらかじめ与える必要がある。ここでは，すでに 著者らがハイパボリック波の理論を用いて求めた，有限 振幅長波の水深変化による波高変化の理論曲線 ${ }^{5}$ を用い て， $h_{1}$ での波高 $H_{1}$ を与えることにする。すなわち， 沖波波形勾配 $H_{0} / L_{0}\left(H_{0}\right.$ : 沖波波高) を与え, $h_{1} / L_{0}=$ $0.0157\left(h_{1} / L=1 / 20\right)$ における $H_{1} / H_{0}$ の值を上述の理論 曲線から求め, これらの值から $H_{1} / h_{1}=\left(H_{1} / H_{0}\right) \times\left(H_{0} /\right.$ $\left.L_{0}\right) /\left(h_{1} / L_{0}\right)$ を求める。なお, ハイパボリック波の理論 曲線から， $h_{1} / L_{0}=0.0157$ では, $H_{0} / L_{0} \geq 0.006$ の波は すでに砕波を起こしており，この理論が適用される波の 沖波波形勾配はかなり小さい值に限られることになる。

さらに底勾配 $i$ を与えれば，3.(2) で述べたように， $a / h_{1}$ を求めることができる。ただし，実際に計算する とわかるが, 同じ沖波波形勾配に対し, 底勾配が小さく なるほど，また同じ底勾配 $i$ に対し，沖波波形勾配が 大きくなるほど $A^{(2)}{ }_{1} / A^{(1)}{ }_{1}$ の值が大きくなり 1 に近い 值になる。この理論の適用範囲としては, 2.(4) で述べ たように底勾配 $i$ によって $T \sqrt{g / h}$ の最大值が与えら れていたが，ここではさらに式 (35) で与えられる第 2 次近似解の係数 $A^{(2)}$ が第 1 次近似解の係数 $A^{(1)}$ より 小さい範囲を限界として計算を行なうことにする。した がって $H_{0} / L_{0}$ の值が大きくなるほど，計算しうる底勾 配の值は大きい值に限られてくる。

\section{（2）数值計算結果}

具体的な数值計算は, 沖波波形勾配 $H_{0} / L_{0}$ が 0.004 , $0.002,0.001,0.0004,0.0002$ および 0.0001 の場合に ついて行なった。(1) で述べたように，計算をはじめる 最大水深を $h_{1} / L_{0}=0.0157$ として, エネルギー・フラッ クスの方法による 理論曲線(5) からそれぞれの $H_{0} / L_{0}$ に 対応する $H_{1} / H_{0}$ を求め, さらに底勾配 $i$ を与えれば, 3. (2) で述べたように $a / h_{1}$ が求まる。底勾配 $i$ として は, $1 / 10,1 / 20,1 / 30,1 / 50,1 / 100$ および $1 / 200$ の 6 種類の值を与えたが，（1）で述べた底勾配に対する制限 から, $H_{0} / L_{0}=0.001$ に対しては $1 / 100$ より, $H_{0} / L_{0}=$ 0.002 に対しては $1 / 50$ より, $H_{0} / L_{0}=0.004$ に対して は $1 / 20$ より大きい勾配についてだけ計算を行なった。

すでに 2.(4) の適用範囲のところで述べたように， 計算可能な水深 $h$ には最小值が存在する。その関係は 式 (29) で与えられるが，微小振幅波の沖波波長 $L_{0}$ を 用いると，
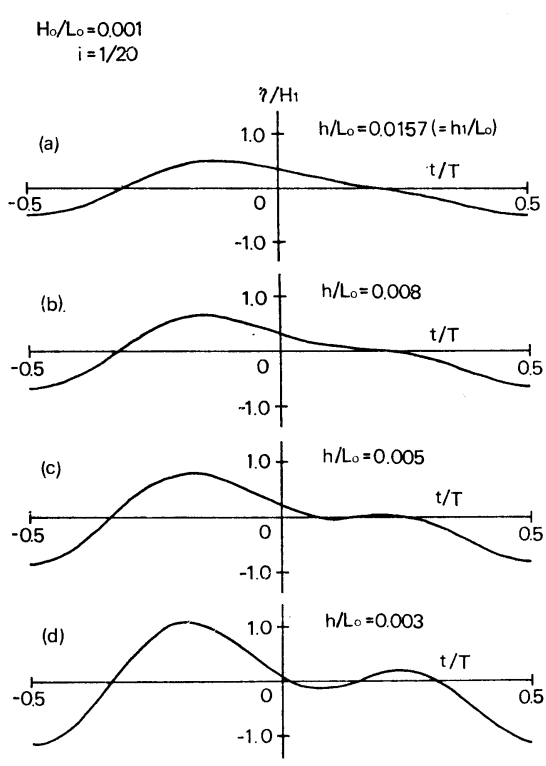

図一6 水深減少による波形変化

$h / L_{0} \geq i^{2} / 8 \pi$

となる。したがって,この最小值は底勾配 $i$ によってき まり，上述の計算を行なう $i$ については，1/10 に対す る約 0.0004 が最大である。実際には, 計算を行なった 最小の水深 $h / L_{0}$ は 0.0003 とした。ただし, 水深が減 少するにつれて, $A^{(2)} / A^{(1)}$ の值は増加するので, $A^{(2)} /$ $A^{(1)}=1.0$ になったところで計算をうち切った。

このような手順で, 各 $H_{0} / L_{0}$ に対する各 $i$ について, $h / L_{0}$ を $h_{1} / L_{0}$ から順次小さくして, 式 (34) および式 (35) から, それぞれの $h / L_{0}$ における $\eta / h_{1}$ を求めた。 なお, 数值計算はすべて京都大学大型計算機センターに よった。その結果の一例が 図一6 である。ただし, 図 中では, $\eta / h_{1}$ のかわりに $H_{1} / h_{1}$ でわった $\eta / H_{1}$ を示し ている。横軸は $t / T$ をとって, 波の 1 周期における時 間的な波形を示している。この例は, $H_{0} / L_{0}=0.001$ で $i=1 / 20$ の場合であり, 上から順に, $h / L_{0}$ が減少する。 (a) は適用範用の最深点にあたる $h / L_{0}=h_{1} / L_{0}$ であり， この場合の $A^{(2)} / A^{(1)}$ は約 0.25 , 最後の (d) は $h / L_{0}$ $=0.003$ の場合で, $A^{(2)} / A^{(1)} \fallingdotseq 0.85$ である。 4 つの波形 $\eta$ はすべて最深点での波高 $H_{1}$ でわっており，(a)にお ける $\left(\eta / H_{1}\right)_{\max }-\left(\eta / H_{1}\right)_{\min }=1.0$ から, (b), (c), (d) と水深が浅くなるにつれてその值は増加し，(d) では 2 以上になっている。しかも, 波形は, 波の峯の前面がし だいにきりたち, 後面ではしだいにゆるやかになって, 非対称な前かがみの形になっていくことがわかる。この ように，いままで理論的に明らかにされていなかった水 深減少による波形の非対称化がこの解によって説明でき る。 


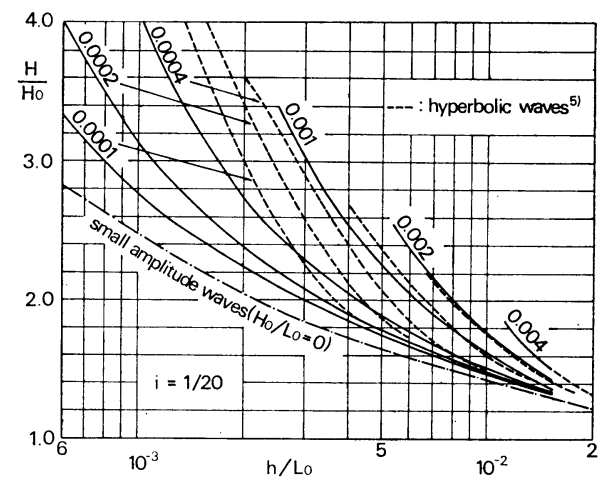

図一7（1）波高変化に及ぼす沖波波形勾配の影響

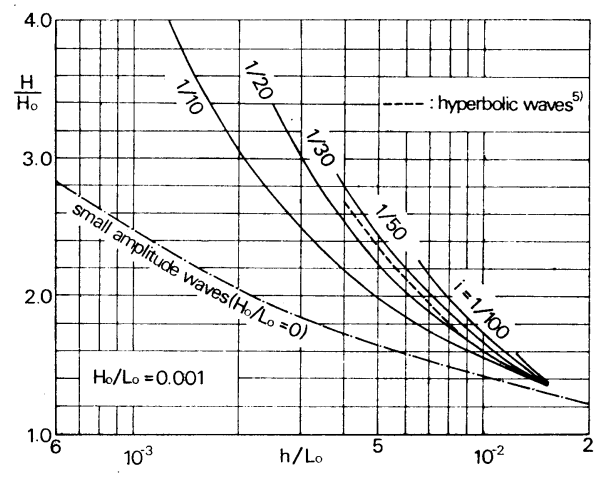

図一7（2）波高変化に及ぼす底勾配の影響

いま波高の変化に注目し, 従来の shoaling の理論曲 線と同様に, 横軸に $h / L_{0}$, 縦軸に $H / H_{0}$ をとって示し た例が，図一7 (1)，(2) である。（1）は底勾配 $i=1 / 20$ で沖波波形勾配 $H_{0} / L_{0}$ をかえた場合，（2）は $H_{0} / L_{0}=$ 0.001 で $i$ をかえた場合である。なお（2）の場合は, 上述のように $i=1 / 200$ については計算していない。図 中同時に示している破線は, ハイパボリック波のエネル ギー・フラックス一定の仮定から求めた理論曲線(5であ り，一方，一点鎖線は同様に微小振幅波理論によるもの である。図では $H / H_{0} \leq 4.0$ の範囲で示しているが, 理 論曲線が $H / H_{0}<4.0$ でおわっている ものは，そこで $A^{(2)} / A^{(1)}=1.0$ になったことを意味している。ここで示 さなかった計算結果をも含めて, 次のようなことがいえ る。

まず，いずれの場合も微小振幅波理論のエネルギー・ フラックス一定の仮定から得られた值よりも大きく, 水 染の減少に伴う波高増加の割合は大きい。また，八イパ ボリック波の理論曲線と同様, 沖波波形勾配が大きいほ ど，同じ底勾配の值に対して波高増加の割合は大きい。 ただし，值そのものは，図一7(1) でも見られるよらに， 同じ底勾配に対して，沖波波形勾配が小さくなるほど八 イパボリック波の理論值よりその増加の割合は小さくな る。同じ沖波波形勾配に対して, 底勾配 $i$ が小さいほ

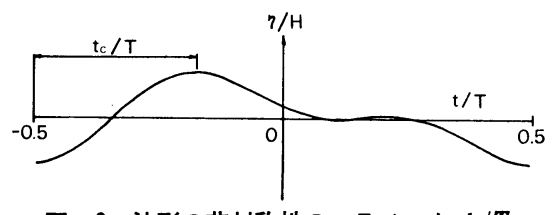

図一8 波形の非対称性のパラメータ $\boldsymbol{t}_{c} / \boldsymbol{T}$

ど波高増加の割合は大きい。この傾向は, 式 (44) の右 辺第 2 項の係数に $i^{-1}$ が含まれていることからも予想で き, この事実は水深の変化に伴う波高の変化に関し, 従 来理論的に明らかにされていなかった底勾配の影響を明 らかにしたものである。

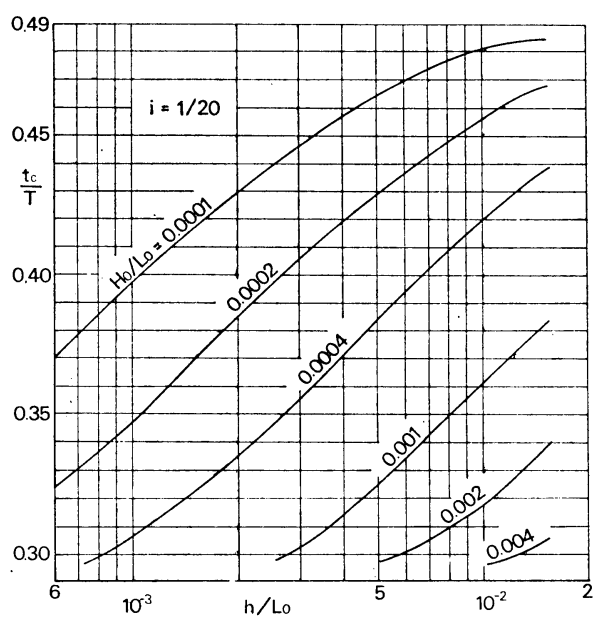

図一9（1）水深隇少による波形の非対称化に 及ぼす沖波波形勾配の影響

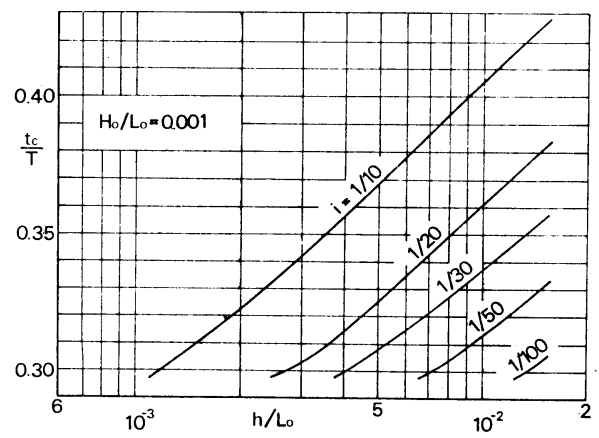

図一（2）水深隇少による波形の非対称化に 及ぼす底勾配の影響

次に, 図一6に示した時間波形において, 前面の谷か ら峯までの時間を $t_{c}$ (図一8 参照) として, $t_{c} / T$ の水深 減少による変化の例を示したのが 図一9 (1), (2) であ る。図-7 (1),(2) と同様,（1）は底勾配 $i=1 / 20$ の場 合，(2）は沖波波形勾配 $H_{0} / L_{0}=0.001$ の場合である。 図から, 水深の減少に伴い $t_{c} / T$ の值が減少し, 波形が 前かがみな非対称な形になっていくことが明らかであ る。図に示した例をも含めて, 同じ底勾配に対しては沖 
波波形勾配が大きいほど，また同じ沖波波形勾配に対し ては底勾配が緩やかなほど同一の $h / L_{0}$ に対し波形がよ り非対称な前かがみの形になることがわかる。なお，1. で述べたように, Biesel ${ }^{7)}$ は波形の非対称性を表現する 量として, 波の峯の前面の勾配と後面の勾配の平均値を とり，その值を理論的に導いているが，ここでとりあげ た $t_{c} / T$ は, Adeyemo ${ }^{18)}$ が実験的に検討したいわゆる “wave horizontal asymmetry”に対応するものであ る。波形の非対称性が水粒子速度の時間変化の非対称性 に対応し, したがって, 構造物に加わる波力あるいは底 質の運動に影響することを考えれば，ここでとりあげた $t_{c} / T$ は, Biesel のパラメータ以上に 重要な工学的意味 を有するものと考えられる。

\section{5. 従来の実験結果との比較}

以上の理論結果の妥当性を検討するため，従来の実験 結果と比較してみる。水深変化による波高変化に及ぽす 底勾配の影響あるいは波形の非対称性に関する従来の研 究はきわめて少なく，また理論の適用水哚がかなり小さ いため, 直接比較しうる実験結果はきわめて少ない。

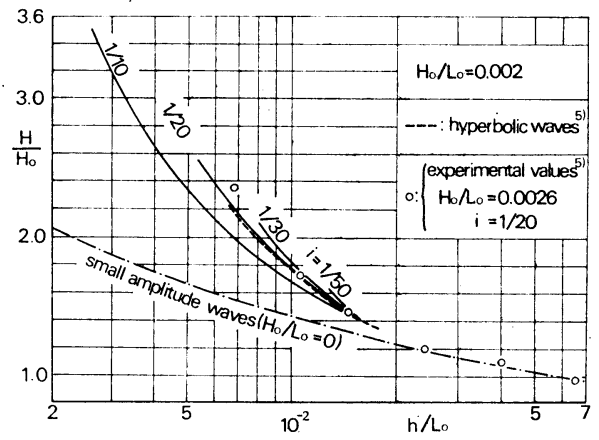

図一10 波高変化の理論曲線と従来の 実験結果 ${ }^{5)}$ との比較

図一10 は, $H_{0} / L_{0}=0.002$ の場合の波高変化の理論曲 線を, 著者らがかつて 行なった shoaling の実験結果 ${ }^{5)}$ から $i=1 / 20, H_{0} / L_{0}=0.0026$ の場合の 波高変化の実験 值を引用し比較したものである。 $H_{0} / L_{0}=0.0026$ という 值は, この実験のケースの值の中でもっとも小さいもの であり，そのつぎに小さい值が 0.0060 で，すでにこの 理論の適用範囲外であるため, 比較しうる唯一のケース である。理論と実験の $H_{0} / L_{0}$ の值は正確には一致して いないが， $i=1 / 20$ の理論曲線と実験值はほぼ一致して いるといえる。ただし，図一10 の実験值はたまたま理 論值と一致したとも考えられる。いずれにせよ， $H_{0} / L_{0}$ の值のさらに小さい場合の実験結果がなく, しかも $1 / 20$ 以外の底勾配についての実験結果がないため,これ以上

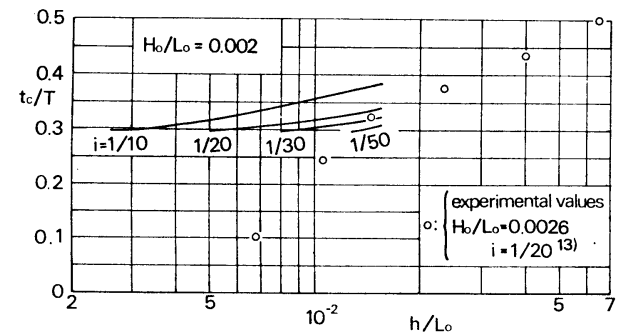

図一11 波形の非対称性の変化の理論曲線と 従来の実験結果 ${ }^{13)}$ との比較

の検討はできない。

最後に, 図一9に例として示した波の非対称性を表わ すパラメータ $t_{c} / T$ の変化の理論曲線を, 実験結果 ${ }^{13)}$ と 比較したものが，図一11 である。理論曲線は，実験結 果と同じく水深の減少とともに $t_{c} / T$ が減少する傾向を 示しており，波形の前かがみの程度が増すことを示して いるが, $i=1 / 20$ の理論曲線の存在する範囲がせまく, しかもその範冊では実験值は理論值よりもはるかに小さ くなっている。図一10 の波高変化の場合と同様, 他の 実験結果がないため,これ以上の論議はできない。

以上のように，比較しうる従来の実験結果がきわめて 少なく，しかも波形の非対称性については，その数少な い実験結果とも定量的には一致せず，定性的にその傾向 を説明し得たにすぎない。波形に関しても，一般に実験 波形は一様水深の場合と同様, 水深・波長比の小さい波 の特性として，波の峯がするどく谷が平坦で，波の谷と 静水位との間の距離が半波高より小さいのに対して, 図 -6 に例示した理論波形は, 谷と静水位との間の距離が ほぼ半波高に等しい。このような理論と実験結果との相 違の原因として，砕波点に近づくにつれて非線型性が増 大し, 第 2 次近似解では次数が十分でないことが考えら れる。

\section{6. あとがき}

本研究は，従来理論的に明らかにされていなかった， 斜面上を進行し変形して砕波にいたる波の，水深減少に よる波高変化に及ぼす底勾配の影響と波形の非対称化を 理論的に明らかにするため，第 1 次の浅水理論を用い， せつ動法によって，一様勾配斜面上を進行し変形する有 限振幅長波の解を求め, その結果を検討し図示するとと もに，数少ない従来の実験結果と比較検討したものであ る。

水深減少による波高増加に及ぼす底勾配の影響につい ては，同じ沖波波形勾配に対し，底勾配が緩やかなほど 波高増加の割合の大きいことが理論的に明らかにされ た。 
水深減少による波形の非対称化に関しては，水深減少 とともに波形がより前かがみな非対称な形になることを 理論的に明らかにし，定性的には従来の実験結果の傾向 と一致することを示すとともに，沖波波形勾配が大きい ほどまた底勾配が緩やかなほど，同じ水深・沖波波長比 に対してその傾向が著しいことを理論的に明らかにし た。

この研究は著者らが数年来続けている有限振幅波とそ の shoaling に関する研究の一部をなすものであり,こ れまでに得られた多くの新しい知見とともに，この研究 成果がこの方面の学問の進歩と実際問題への応用に貢献 できれば幸いである。

\section{参考 文 献}

1) Le Méhauté, B. and L.M. Webb: Periodic gravity waves over a gentle slope at a third order of approximation, Proc. 9 th Conference on Coastal Engineering, pp. 23-40, 1964.

2）岩垣雄一・酒井哲郎：有限振幅波の shoaling について, 第 14 回海岸工学講演会講演集, pp. 1-7, 1967-10.

3) Friedrichs, K.O. : Water waves on a shallow sloping beach, Comm. on Pure and Applied Math., Vol. 1. pp. 109-134, 1948.

4) Tlapa, G.A., C.C. Mei and P.S. Eagleson : An asymptotic theory for water waves on beaches of mild slope, M.I.T. Hydrodynamics Laboratory Report No. 90, 1966.

5）岩垣雄一・酒井哲郎: 有限振幅波の shoaling について (2), 第 15 回海岸工学講演会講演集, pp. 10-15, 196812 .

6）合田良実：砕波指標の整理について，土木学会論文報告 集 No. 180, pp. 39-49, 1970-8.

7) Biesel, F.: Study of wave propagation in water of gradually varying depth, Gravity Waves, Circular No. 521, Nat. Bureau of Standard Washington D.C., 1951.

8) Stoker, J.J. : Water Waves, Interscience Pub., Inc., New York, pp. 22-32, 1957.

9）本間 仁：長波の変形について, 土木学会誌, 第 19 巻, 1933.

10) Carrier, G.H. and H.P. Greenspan : Water waves of finite amplitude on a sloping beach, Jour. of Fluid Mech., Vol. 4, pp. 97-109, 1958.

11) Ichiye, T.: Some remarks on the non-linear theory of shallow water waves on a sloping beach, The Oceanographical Magazine, Vol. 4, No. 4, Japan Meteorological Agency, pp. 159-166, 1953.

12) Bourodimos, E.L. and A.T. Ippen : Wave transformation in an open channel transition, Proc. of ASCE, Vol. 94, No. HY. 5, pp. 1317-1329, 1968.

13）岩垣雄一・酒井哲郎：クノイド波に関する研究（第 7 報） 一shoaling に関卞実験一, 京大防災研究所年報, 第 12 号 B, pp. 569-583, 1969-3.

14) Green, G. : On the motion of waves in a variable canal of small depth and width, Camb. Trans. Vol. VI, 1837.

15) Laitone, E.V. : The second approximation to cnoidal and solitary waves, Jour. of Fluid Mech., Vol. 9, pp. 430-444, 1961.

16）岩垣雄一：波の変形論, 1967 年度水工学に関する夏期研 修会講義集, B. 海岸・港湾 コース, 土木学会水理委員 会, 1967-8.

17）石原藤次郎 - 本間 仁: 応用水理学, 上, 丸善, p. 126 . 1957.

18) Adeyemo, M.D. : Effect of beach slope and shoaling on wave asymmetry, Proc. 11 th Conference on Coastal Engineering, pp. 145-172, 1968.

(1971.6.16 · 受付) 